\title{
Hirata Kiyoaki and His Thoughts on Civil Society
}

\author{
Toshio Yamada
}

\begin{abstract}
:
Hirata Kiyoaki is a representative historian of economic thought in postwar Japan, a renovator of Marxism, and, above all, a theoretician vis-à-vis civil society. The thinkers he principally examined were Quesnay, Marx, and Gramsci. Through the study of these three theoreticians, his thinking on civil society germinated, fully developed, and finally experienced a sort of change. In this essay, I will follow the development of and changes in his theory, as well as his original and fundamental analytical approach with regard to economic society; in so doing, I wish to elucidate the contemporary significance and limits of his civil society theory.

The original nature of Hirata's theory resides in the fact that he analyzes economic society from a "process and structure" approach. In early Hirata's study of Quesnay, this was expressed in terms of the methodological pivot of the "circuit of productive capital and structure of reproduction," leading to a solution of the so-called enigma of the Tableau économique. In middle-aged Hirata's study of Marx, he began to place the greatest analytical emphasis on the "capital circuit" or "process," rather than on "structure." This resulted in an exploration of problems pertaining to property: the inversion of the law of appropriation and the re-establishment of individual property. Here we see the full development of his theory of civil society, which addressed many pressing questions posed with respect to actual issues of the times: civil society and community, civil society and capitalism, and civil society and socialism. Later-years Hirata adopted the Gramscian theory of hegemony, thus shifting his attention to a civil society theory that differed from that of his younger years. By stressing the Gramscian genealogy of the word régulation of the French régulation school, it seems that he had found in this concept his own approach to "process."

In other words, his initial approach to "structure," another one in his younger days, may have gradually faded away, or his death may have hindered him from the active development of this approach. However, as a cost of it having not been developed, his thoughts on the "re-establishment of individual property" - which he substantiated as part of his approach to "process"- have become something that does retain universal value even today.
\end{abstract}

JEL classification numbers: B 14, B 31, B 52.

The History of Economic Thought, Vol. 56, No. 1, 2014. (C) The Japanese Society for the History of Economic Thought. 


\section{Life and Works of Hirata Kiyoaki}

Hirata Kiyoaki ${ }^{1}$ (1922-1995) was a historian of economic thought who took an active part in Japanese society in the latter half of the 20th century; he was also a renovator of Marxism. Above all, however, he was a theoretician with regard to "civil society." Born in Tokyo, he studied under the direction of Takashima Zenya (1904-1990) at the Tokyo College of Commerce. ${ }^{2}$ Following graduation and after having received some teaching experience in various universities, he became a professor of economics at Nagoya University and then Kyoto University. He died suddenly in the middle of his tenure as president of Kagoshima Keizai University. ${ }^{3}$

Analyzing Hirata is indeed very difficult; his works are extremely voluminous ${ }^{4}$ and crabbed. However, his works generally focus on three key pillars: F. Quesnay, K. Marx, and A. Gramsci. In referencing each of these three thinkers, we can also divide his intellectual activities into three distinct periods, during which his thinking on civil society gradually formed, matured, and finally transformed.

The first of those periods took place between Japan's defeat in World War II and the early 1960s. During this period, Japan saw an upsurge in movements promoting democracy and socialism and, since the mid-1950s, a high and durable rate of economic growth; the latter was the period during which the prototype of Japanese postwar capitalism was built. Young Hirata wrote many articles on the English and French classical political economy as well as on Marxism; he also translated some French books, including Marx's Misère de la philosophie. These works of early Hirata would be crystallized into a voluminous work, Creation of Economic Science (1965).

The second of the three periods, from the late 1960 s to the early 1980 s, was an age of great political upheaval worldwide. In the capitalist world, the previous "golden age of capitalism" finally came to an end in the stagflation crisis of the 1970s; in the socialist world, we saw the darkness of this system, especially as it manifested in the Sino-Soviet split in the 1960s, the Russian invasion of Czechoslovakia in 1968, and the deadlock experienced by socialist economies. Amidst these upheavals, Hirata vigorously developed a civil society

1 In the main text, I follow the Japanese custom of placing the family name first.

2 This institution is the predecessor of Hitotsubashi University.

3 This institution is the predecessor of the International University of Kagoshima.

4 For a list of his works, see Asai and Wakamori (1983) and Nozawa (2008); for his simplified curriculum vitae and profiles, see Souzou-no-kai (1996). 
theory based on his investigation of Marx's texts, resulting in severe critiques of the realities of Japanese capitalism and socialism. This was the most fruitful period of Hirata's career, and he garnered much attention in Japan. Works representative of this period are Civil Society and Socialism (1969) and Political Economy and Philosophy of History (1971).

The third of these periods corresponds to the decade from the mid-1980s to his death in 1995. The Japanese economy experienced the burst of a financial bubble in 1990/1991, following worldwide admiration in the 1980s (as embodied in a book entitled Japan as Number One). In the Eastern European countries, a series of collapses among socialist regimes were triggered by civil revolutions in 1989, culminating in the dissolution of the Soviet Union in 1991. Hirata in this period, going beyond the field of the history of economic thought, began to energetically discuss current affairs: contemporary capitalism, existing socialism, the European Community, French polity and economy, and Japan-Europe comparative civilization, among other topics. During this period, he published Civil Society and the Régulation (1993), which shows his original interpretation of Gramsci and French régulation theory.

\section{Quesnay's Tableau économique and the Circuit of Productive Capital}

1. Questions to be examined about Hirata include how the three pillars or periods are related, and how they developed and changed-or, rather, how his thinking vis-à-vis civil society germinated, flourished, and eventually transformed. In my view, the key to understanding his thinking lies in his study of François Quesnay's Tableau économique, or in the viewpoint of the "circuit of productive capital" discussed persistently in Hirata (1965).

The circuit of productive capital is a form of capital circuits developed in Karl Marx's Capital, volume 2. Here, Marx defines the circuit of productive capital $(P . . . P)$ as a form that typically expresses the exchanges between mankind and nature (i.e., the reproduction of everyday life), in distinction from the circuit of money capital $\left(M . . . M^{\prime}\right)$ which exclusively shows the self-valorizing nature of capital, and in distinction from the circuit of commodity capital $\left(C^{\prime} \ldots C^{\prime}\right)$ which implies an interrelation with and the reproduction of total social capital. According to Marx, mercantilism understood capitalism as being established on $M . . . M^{\prime}$, the classical school, on $P$...P, and the physiocracy of Quesnay, on $C^{\prime}$... $C^{\prime}$. While not denying that the Tableau économique is ultimately established on $C^{\prime}$... $C^{\prime}$, Hirata stresses that there obviously exists a perspective of $P$...P at the very heart of Quesnay's thinking, and that his economic system comprises an Aufhebung of $P$...P into $C^{\prime}$... $C^{\prime}$. There exist at first, says Hirata, movements in 
time of productive capital, which then result in an interrelation of circuits of commodity capital or a spatial structure of social reproduction. This was Quesnay's perspective on the eve of the French Revolution, as well as Hirata's in Japan's age of high economic growth. He declares his own theme in the afterword of his first book, as follows:

Since political processes and economic theory-which had been harmonious for several years just after Japan's defeat in the war-became antagonistic and showed tragic aspects, with a turning point in 1955-1956, the task of revitalizing the philosophy of history by creating a new economic criterion has become, so to speak, a main theme in all of my studies. I sincerely wanted to learn from the classical literature what kind of critical theory had been hitherto acquired by humans about the following point: a structure composed of many processes where human beings who live in the time of economy-or, historical time that is defined by cycles of turnover of capital [i.e., circuits of productive capital] — through their reproduction of everyday life soaked in ordinary sentiment, are going to reproduce by themselves social relations as a system that will be reified in a material-industrial structure. ${ }^{5}$

(Hirata 1965, 564)

Japan in 1955-1956 found itself at the start of a period of high economic growth and an enduring and stable political regime governed by conservative power. Since then, the Japanese populace has been part of a mass consumption society and a company-centered society. Democratic movements that arose shortly after the defeat in war began to decline after reaching a peak, with the mass movement protesting in 1960 the Japan-U. S. Security Treaty. Under these circumstances, how does the reproduction of people's everyday lives (i.e., the circuit of productive capital) build up new material-industrial interrelations (i.e., the structure of reproduction)? This was Hirata's question, and in the process of searching for theoretical criteria for it, he became absorbed in the work of Quesnay.

2. Since the interwar period, it has been a characteristic feature of the Japanese study of the history of economic thought to delve into the classical literature of political economy while focusing on the problems inherent in Japanese capitalism. A characteristic unique to Hirata was that he was greatly influenced

5 Italics and text within square brackets have been added by Yamada for emphasis and clarity, respectively. Unless otherwise noted, this is the case throughout the remainder of this paper. 
by Uchida Yoshihiko (1913-1989), ${ }^{6}$ who was elderly when Hirata became close friends with him. How should one understand, and generate the best results from the "Debate on Japanese Capitalism" in the 1930s-especially with regard to the methodology of the Koza-ha School, represented by Yamada Moritaro (1897-1980) ? $^{7}$ This question underpins Hirata's aforementioned afterword, whose thinking ultimately succeeded from Uchida. Uchida says:

[One needs] to cut the picture of Japanese capitalism in a round slice. This succeeds to the way of thinking of the Koza-ha School, especially as embodied in Professor Yamada Moritaro's Analysis of Japanese Capital$i s m$... . Of this book, there have been many critiques; for example, "there is in it only a typology but never a development.”. . As a matter of economic theory, such critiques finally stem from the impossibility of understanding Yamada's analytical method of Japanese capitalism, i.e., that of the application of Marx's theory of reproduction. . . . This controversy implies an opposition of two methodologies; either one shows a structure of reproduction by cutting each moment of capitalism into round slices, or one shows an outline of a historical stream along with a flow in time of economic development. To cut into round slices ... means to understand a country's structure of reproduction as a consequence of interrelations among circuits of productive capital. ... In short, Yamada's method shows historical movements exactly in a cross section of any given moment.

(Uchida 1967, 85-86; italics added by Uchida)

6 On Uchida Yoshihiko, another representative economist belonging to the Civil Society School of post-World War II Japan, see Yamada (1987; 1988; 1998), Keane (1998, 1214), Barshay (2004, chap. 6), and Suzuki (2013).

7 In the 1920s, Japan saw its first Japanese-language translation of Marx's Capital; however, the capitalist world depicted in Capital differed greatly from Japan's socioeconomic realities of the time. The greatest issue was how to estimate "feudal remnants," which then existed extensively throughout Japan. Were they transitory features that would disappear along with the capitalist development of Japan, or structural features that would necessarily survive as long as Japan remained capitalist? Were they a result of Japanese "backwardness" in its stages of capitalist development, or a necessary constituent peculiar to Japanese capitalism? These questions provoked a great number of disputes that comprised the so-called debate on Japanese capitalism among Japanese Marxists in the 1930s. The Ronoha School considered feudalism a product of Japan's backwardness in terms of its developmental stage, and insisted that Japan would converge with advanced capitalist countries in proportion to Japan's capitalist development. On the other hand, the Koza-ha School, headed by Yamada Moritaro's Analysis of Japanese Capitalism (1934), stressed the impossibility of dissolving feudalism under capitalism, that its survival was, therefore, inevitable, and that it would result in a specific type of Japanese capitalism. 
The methodology of Analysis - termed the "application of the theory of reproduction"-is, says Uchida, to draw a picture of the "cross sections" by "cutting into round slices" the "flow in time" of dated history. Drawing a cross section does not mean ignoring the flow of history; rather, it is recognizing how history has been "poured" into a cross section of any given moment. One finds history in a cross section and processes in a structure. According to Uchida, this is the methodology of Analysis; as for economic theory, this means that, even when one follows "the circuit of productive capital" (vertical section), one should have a perspective of "a country's structure of reproduction" (cross section) that is objectively formed by an intervolution of the circuits of productive capital. Uchida finds this methodology within Yamada's work; Hirata, following in the footsteps of Uchida, detected it in the theoretical development of Quesnay's Tableau économique, from the archetype to the complete form.

If we thoroughly follow the cycles of the turnover of productive capital, it will necessarily lead to a recognition of the structure of reproduction of the total social capital, and to a jump of $C^{\prime}$... $C^{\prime}$ as a circuit formula of individual capital to a law of reproduction of a society as a whole.... Quesnay was successful, under a "physiocratic deviation" that agriculture alone is productive, in understanding immediately the logical relevance of the circuit, turnover, and structure of the reproduction of capital, and in this way in creating an economic science that centers on the theory of reproduction.

(Hirata 1965, 339-40)

A certain circuit theory underpins Quesnay's reproduction theory: reproduction theory that also contains circuit theory. Reproduction theory must be understood in relation to circuit theory. These are Hirata's messages, and in this way, he analyzed the formation process inherent in the Tableau économique by using the logic of Capital. Through his work, Hirata at the same time contributed to (1) a new reading of Capital, (2) the development of Uchida's ideas of "flow in time" and "cutting into round slices," (3) the confirmation of the relevance of Yamada's methodology, and (4) the establishment of his own "economic criterion" for critical recognition of the postwar Japanese economy.

3. What did Hirata's first-period works mean with regard to the formation of his civil society theory? Of course, he hardly developed his own civil society thought in this period; nevertheless, he did pose some germinal questions on, or theoretical recognitions of, civil society. Let us examine three important points.

First, he studied in his student days under the direction of Takashima Zenya, one of the pioneers of civil society thought in Japan; also, from the early 
times of his professional career, he was a best friend of Uchida Yoshihiko, another pioneer of civil society thought. When he translated Misère de la philosophie, he was deeply interested in Marx's distinction between "société bourgeoise" and "société civile" (Hirata 1993, 243-48).

Second, he stressed above all the importance of the circuit of productive capital, rather than that of money capital or commodity capital. The optics of the circuit of productive capital that opens with production and ends in production, although implying a risk of "naturalizing" the capitalist society, can lead to the recognition of a society that comprises people's concrete production and everyday lives. That he chose these optics serves as a decisive cornerstone in the full-scale development of civil society theory in his second period of work.

Third, the perspective of "the circuit of productive capital and reproduction" is more broadly developed into one of "process and structure" or "formation and structure." When Hirata (1965) says at various points that a society or history must be understood in terms of a simultaneous understanding of both "a structural (spatial) summary of process (time)" and "a processing (flowing in time) contents of structure (space)," he is referring, by using the word "process," to a world where there exist concrete relationships among actual human beings and, by using the word "structure," to an abstract and reified interrelation lacking concrete realities. This perspective of "process" is characteristic of his later-years civil society theory.

In looking back at the time of his first book, Hirata says the sprouting of a new type of capitalism in Japan since 1955-1956 had brought about the first opportunity to pose questions with respect to civil society. "The capital circuit/ reproduction process and reproduction structure ... proceed as metamorphoses of money and commodity. A 'civil society' as such—that is, 'civil society' in the development of capitalism-became problematic in my consciousness for the first time" (Hirata 1977, 112). Among the many civil society theories, his theory is original in that it stemmed from the development of capital circuit theory.

\section{Marx and Civil Society}

1. Immediately following the publication of Hirata (1965), he started to study Marx in earnest, developing in the subsequent 20 years an interpretation of Marx as a thinker of civil society. While civil society theory in Japan had until then considered Marx an opponent of civil society, a concept developed mainly with an eye to Adam Smith or other Enlightenment thinkers, the originality of Hirata consists in his finding of civil society thinking directly within Marx's texts. It is for this reason that Hirata's thinking has been said to belong to the "Marxist School of Civil Society." The Marxian literature to which Hirata at- 
tached special importance are Grundrisse (1973) and the French edition of Capital (1967). The former is one of the first manuscripts of Capital, as well as new documents that became for the first time generally available in the 1950s. The latter is the last version of Capital that was published under the eyes of Marx himself and has been ignored in spite of its proper value in terms of research material.

Hirata first tackled Grundrisse. His analytical approach was, as a matter of course, that of circuit theory. While the first article on Marx following the publication of Hirata (1965) had been entitled "Political Economy and Philosophy of History in Marx" (Hirata 1966), the title was changed to "Circuit-Accumulation Theory and Philosophy of History" on the occasion of reprinting (Hirata 1971). Thus, for Hirata, Marx’s system of economic theory was born first and foremost from making a core "circuit-accumulation theory." By using this specific terminology, he implies an accumulation theory comprehended in, or stretched to, the range of the capital circuit. Hirata's subject is on what theoretical pivot was the political economy of Grundrisse established-or, how does circuit-accumulation theory relate there to a famous description of history: "Forms which precede capitalist production"? He himself summarizes the answer:

I have found that the theoretical dimension to which the "Forms" belong was that of the circuit-turnover process as a development of the accumulation process. And I have recognized that this comprehensive understanding of the capital accumulation that was understood in the context of the circuit-turnover of capital would be discussed, in the Capital of Marx in his later years, as a relevance and distinction between the processes of production and circulation (-appropriation), and that here exists a theoretical focus of Marx's perception of the 19th-century world. What is to be pursued is nothing other than a comprehensive understanding of the capital accumulation that unfolds as the circuit-turnover of capital. （Hirata 1971, 5)

Marx's first system of political economy was formed, insists Hirata, not on the pivot of value theory, but of circuit-accumulation theory. In Grundrisse, accumulation theory was developed from the broad perspective of the circuit-turnover of capital. This poses a new problem: property theory. Hirata paid attention to the fact that the circuit-accumulation theory of Grundrisse has in it a passage that refers to the "Forms which precede capitalist production." As is well known, this passage has been frequently cited, mainly in the discipline of economic history; examples include discussions on Asiatic, Roman, and Germanic forms of commune or community. However, according to Hirata, the "Forms" are rather 
discussions on the forms of property than those of communes. The most important question for him is why this passage on property is inserted only within the theory of circuit-accumulation.

For both Marx in Grundrisse and Hirata, the essence of property (i.e., capitalist private property) needs to be clarified precisely with respect to circuit-accumulation theory. The property theory in question is embodied in discussions of the "inversion of the law of appropriation"-that is, a theory on the inversion of bourgeois property based on one's own labor to the capitalist private appropriation of others' labor based on the labor of still others. This inversion of the law of appropriation is uncovered "only at the end of the second cycle" (Marx 1973, 514, italics by Marx). That is to say, "exactly in the circuit-accumulation theory, the essence of bourgeois property is to be critically revealed" (Hirata 1971, 40). This perspective on the inversion of the law of appropriation becomes, for Hirata, a pivotal one in understanding modern society, and it necessarily accompanies discussions on the theme of "civil society" (bourgeois property) and "capitalism" (capitalist private property).

In short, Hirata's perspective on the "capital circuit and the structure of reproduction" since his study on Quesnay now constitutes part of his Marxology, and it has developed into an analytical approach: "circuit-accumulation theory and property theory." Through his understanding of the inversion of the law of appropriation, he uncovered the problematic field of "civil society and capitalism." His theory of civil society flourishes solely on this basis.

2. What is Hirata's concept of "civil society"? This is not necessarily clear. Not only is his terminology ambiguous and polysemous, but both "civil society" and "bourgeois society” (bürgerliche Gesellschaft) in European languages are often translated into the same Japanese term, shimin shakai. ${ }^{8}$ In this period, Hirata uses this word not in relation to the state or politics, but mainly to the ordinary economic lives of people in modern society (i.e., a connotation found in the nuance of bürgerliche Gesellschaft). We can see in Hirata's famous book Civil Society and Socialism (1969) at least three implications of civil or bourgeois society.

First, a civil society is, according to Hirata, a society that is rooted in the concrete aspects and ordinary lives of people. "Civil society is first of all a soci-

8 In this paper, I use the term "civil society" as an English translation of the Japanese shimin shakai, except in special cases. In Japan, at least until the 1970s, the concept of shimin shakai had been principally used not in the connotation of particular private (not public) groups or associations, but in that of a social formation on the national level, and at the same time, with an implication of something modern, occidental and positive vis-à-vis the feudal elements in Japan. 
ety where ordinary people interrelate one to another as independent people, exchange one's products with others', and communicate his/her will to each other" (Hirata 1969, 86). Remembering the terms he used in his study of Quesnay, one can see civil society is a society understood in terms of the "processes of concrete human beings" who are not yet reified in the objective structure, or "a development itself as an economic and social process of the property and division of labor" (175; italics by Hirata). The perspective of the circuit of productive capital operates under his concept of civil society, as shown in his use of the terms "concrete human beings" and "process." Nonetheless, the concept of civil society in this sense is too abstract to be used to specify some aspects of modern society.

Second, his concept of civil society covers a society of private individuals endowed with freedom and equality. "Civil society is one where people communicate one to another as citizens," he says. "Here, citizens constitute a real base of juridical subjects with freedom and equality" (Hirata 1969, 79). A free and equal person is a product par excellence of modern Occidental societies; it has been born through struggles with traditional communes and arises from the aftermath of their destruction. Furthermore, civil society is something to be evaluated positively. When Hirata says that civil society is a society constituted by free and equal private proprietors in the modern Occident, he recognizes that "civil society" stands in opposition to the "traditional commune." From here, his problematic approach to "civil society and the commune" develops into a comparative discussion of civilization in the Occident and Japan/Asia, or into a criticism of premodern elements that survive even today in Japanese capitalism.

The concept of civil society as such is not necessarily original to Hirata. It has been shared among not a few Japanese debaters, in the context of something akin to Adam Smith's “commercial society." It is apropos to consider Hirata's concept from this perspective as having evolved from a shared concept. ${ }^{9}$

What is original to Hirata, however, is found in the fact that he defined civil society as a society of "individual property" from the viewpoint of property theory. In distinguishing the premodern commune from civil society by virtue of the criterion of the existence or non-existence of "individual property," he says that

... the property of the members of a civil society is, although superficially

9 On this point, the following indication is suggestive. "The Japanese concept of civil society is Marx's picture of the early stage of normal capitalism without sharp class antagonisms, but this is superimposed on Smith's civilized or commercial society. In a revolutionary process, what is civil in society is not to be expunged, but rather to be fully realised" (Mizuta 2006, 120, italics added by Mizuta). 
private and exclusive, individual and non-exclusive at its very essence. What a civil society objectively produces is the "individual," "individual labor," and "individual property." . . A civil society, though under a restriction of private exclusiveness, is conscious of the relationship and distinction between the individual and the genus, thus establishing one as an individual.

(Hirata 1969, 88-92)

In short, for Hirata, modern civil society is, unlike premodern communities, a society where individual property is established under the appearance of private property—or to say, rather, a society where, in spite of its creation of individual property, it is transformed into private property.

The third nuance inherent in his idea of civil society is one that contrasts it with capitalist society - that is, civil society within the problematic framework of "civil society and capitalism." According to Hirata, at least in modern Occidental society, civil society exists at the root of capitalist society; hence, modern society must be understood in terms of two strata: civil society and capitalist society. Civil society represents the primary social formation in modern Western society, and only on this basis can capitalism exist as a secondary social formation. The logic that intermediates between civil society and capitalist society exactly encompasses the theory of the inversion of the law of appropriation. Not to mention Marx's Capital, says Hirata, Marx's historical materialism in general also assumes the logic of two strata:

The actual civil society exists in a ceaseless process where it is transforming into capitalist society.... This is why Marx implies also capitalist society in using the terms civil or bourgeois society.... There is not an original historical stage of civil society, as such. Real social formation develops as a constant transformation from the primary one (civil society) to the secondary one (capitalist society).

(Hirata 1969, 52-53)

In Western Europe, capitalism exists as something transformed from civil society (i.e., as a secondary social formation). Although civil society actually exists only as something that has transformed into capitalism, the former must be conceptually distinguished from the latter. Traditional Marxism in Japan has ignored this distinction; its use of overly simplistic definitions for civil or bourgeois society and capitalist society has resulted in the conclusion that civil society needs to be expunged. This, however, is not correct. By distinguishing them, we can gain insights into fresh and important themes: Has Japanese capitalism been based on civil society? Has Japan been a capitalist nation lacking a civil society? Has postwar Japan's high rate of economic growth really brought about 
capitalism that features a civil society? Hirata's question on "civil society and capitalism” has highlighted these analytical approaches vis-à-vis pre- and postwar Japanese capitalism.

3. By confirming in this way what is meant by the term "civil society," Hirata sharply questions the problems inherent in socialism. As was previously mentioned, the many negative aspects of socialist countries grew more apparent in the 1960s and 1970s (e.g., the Sino-Soviet split, the invasion of Czechoslovakia, the stagnation of planned economies). In the midst of these situations, Japanese Marxists continued to adhere only to class struggles, almost ignoring altogether questions relating to individuality and human rights. Criticizing this atmosphere, Hirata bravely questioned the nature of Marx's own socialism.

His conclusion is summarized in his assertion that Marxian socialism represents a "re-establishment of individual property." Hirata's analytical approach is that of property theory, and his analytical method is, from start to finish, that of textual criticism. The subject matter of focus resides in some passages on "the negation of negation," which are included in the chapter or section on the "historical tendency of capitalist accumulation" (Chapter 24, Section 7 of the fourth German edition of Capital, volume 1; Chapter 32 of the French and English editions), that is also in a part of the conclusion of the same volume. While Hirata underscores the errors made in the Japanese translation of the sentences in question, here we quote them from the English edition; it too shares the same mistakes.

The capitalist mode of appropriation, the result of the capitalist mode of production, produces capitalist private property. This is the first negation of individual private property, as founded on the labour of the proprietor. But capitalist production begets, with the inexorability of a law of Nature, its own negation. It is the negation of negation. This does not re-establish private property for the producer, but gives him individual property based on the acquisitions of the capitalist era: i.e., on co-operation and possession in common of the land and of the means of production.

(Marx 1996, 751; cf. Hirata 1971, 485)

The following issue is decisively posed: "This does not re-establish private property for the producer, but gives him individual property. ...” As is well known, the last version of Capital that Marx himself had revised, and for which he was responsible, is the French edition. He directed that on the occasion of new editions, this part in question ought to follow the French edition, which is written thus: "Elle rétablit non la propriété privée du travailleur, mais sa pro- 
priété individuelle. ..." (Marx 1967, 342). In the third (1883) and fourth (1890) German editions, following Marx's direction, this sentence is correctly translated: "Diese stellt nicht das Privateigenthum wieder her, wohl aber das individuelle Eigenthum. ..." However, in the English edition, another verb, "give," is inserted beside "re-establish," as shown: "This does not re-establish . . . but gives him..." On account of this incorrect insertion, the result is that the re-establishment of individual property in a future society, as clearly shown in the French edition, is thoroughly extinguished. The French sentence "Elle rétablit la propriété individuelle du travailleur" must be translated into English as follows: "This re-establishes the individual property of workers." This mistake, insists Hirata, is also found in Japanese translations.

This is not, he says, a mere question of mistranslation, but a serious question concerning Marxists' image of socialism. According to the French edition, Marx says that "a re-establishment of individual property" will be realized in a socialist society as a result of "the negation of negation"- that is, individual property was already established in modern civil society, although it took the form of private property. Through the inversion of civil society into capitalism, private individual property has been transformed into private capitalist property ("the first negation"). Socialism is, by negating again private capitalist property ("the negation of negation"), nothing other than a re-establishment of the original individual property (Hirata 1978). The individual property to be re-established would be a social relation where "the identity of work and property" is realized at the social level (Hirata 1982, 293). "Only by the re-establishment of individual property, the de facto social property [which has been formed in the capitalist era] becomes a real social property" (Hirata 1971, 475).

Thus, for Hirata, it is obvious that socialism represents more "a succession of civil society" than a breaking off from capitalism. "The individuality, individual labor and individual property of the working class, which have been distorted by the private form, are now going to flourish properly in the socialist society.... Therefore, we have to confirm that the revolutionary transition from capitalism to socialism is a gradual succession as well as a breaking off in the world history. Only those who confirm socialism as a succession of civil society have the right to speak of socialism" (Hirata 1969, 104).

His thinking wherein socialism is defined as the "re-establishment of the individual property" and the "succession of civil society" radically renovated the Marxism of the time, which had been soaked in the generally accepted idea that "socialism is nothing other than national property." Besides, his problematic approach to "socialism and civil society" raised an important viewpoint in criticizing existing socialist countries headed by the Soviet Union as embodying "socialism without civil society." Although his words "the revolutionary transition 
from capitalism to socialism" resound today in vain, the essence of his civil society theory, as seen in the concept of the "re-establishment of the individual property," ought to be revitalized in the 21 st century world, be it capitalist or socialist.

In short, middle-age Hirata, as an extension of the perspective of the capital circuit, explored a new theoretical pivot of the inversion of the law of appropriation, resulting in the discovery of the missing concept of "individual property." Circuit theory led to property theory, which in turn led to his original theory of civil society. Thus, he made critical observations on the actual problems of the time, from the approaches of "civil society and the commune" to "civil society and capitalism" to "civil society and socialism."

\section{Gramsci and the Concept of Hegemony}

1. The late 1980 s to the early 1990s represent the last decade of Hirata's life. In this period, there was a great upheaval in the geopolitical structure of the postwar world, as seen on the one hand in civil revolutions in Eastern European countries and the collapse of the Soviet Union, and on the other, by the burst of the bubble economy in Japan after it became an economic power and by the signing of the Maastricht Treaty in 1992. Hirata began to make many comments on current events and also, with respect to theory, to discuss both state and French régulation theory. What is important here is that he adopted anew the civil society theory of Antonio Gramsci (1891-1937); in so doing, his concept of civil society experienced a kind of transformation. While focusing on this point, we follow Hirata in his later years.

With the adoption of Gramsci's theory, Hirata's stance in questioning civil society changed. Formerly, he placed an emphasis, under an approach that envisioned "civil society and the commune" and "civil society and capitalism," on critiques of Japanese capitalism lacking civil society, or capitalist property lacking individual property. However, by adopting the theory of Gramsci, Hirata's problems shifted to those of "civil society and the state." Of course, it is not true that he did not ever deal with this area; rather, one might say that the theme of "civil society and the state" had long underpinned his thinking-at least since the translation of Misère de la philosophie in his younger days-and that this theme had simply been revived with his encounter with Gramsci. In any case, Hirata in his later days discussed civil society in contrast with the state, rather than with the commune or capitalism, and with respect to its political aspect than to its economic aspect as "bürgerliche Gesellschaft." Hirata himself provides this reasoning: 
The more one sticks to contemporary Japan, I keenly believe, the more a common perspective across various generations is required. ... Social relations in a given era are not thoroughly reduced to the economic relations of production ... it is contradictions, given the rhythmic movements by the former, that lead to a transformational process at the dimension of the state... I once again came to confront a classical theme: civil society and the state.

(Hirata 1993, 242-43)

Regarding civil society and the state, there are classically two well-known thinkers: Georg Wilhelm Friedrich Hegel, who argued for the "Aufhebung of civil society to the state," and Marx who, reversing Hegel's argument, insisted on the "re-subsumption of the state to civil society." Hirata pays attention to Gramsci, who, stimulated by Hegel and Marx, conceived a new theory of civil society during his time in prison in the interwar period. What is Gramsci's civil society theory? Hirata explains its essence as follows.

In Russia, where a real socialist revolution took place, civil society was primordial and gelatinous and the state was all; on the other hand, in the West, civil society had already developed, and we see the sturdy structure of civil society when the state trembles. Therefore, when one wants to realize a socialist revolution in Western Europe, there is no other way than winning a war of position in the field of civil society, not a seizing of the state by a war of maneuver, as was the case in Russia. Gramsci discovered the "civil society" between the basis (economic society) and the superstructure (state), and made the civil society the main battlefield for emancipatory movements. In other words, civil society contains political and public elements as well as an ensemble of private interests (system of needs). Therefore, domination by the bourgeois state implies not only a compulsory domination by "political society," but also a process where the ruling classes gain an active agreement of the ruled ones through various private organizations in "civil society," like schools, churches, and associations. Civil society is precisely about achieving agreement through the moral and intellectual leadership of the ruling classes, or an apparatus of their hegemony. It is, therefore, decisively important for socialist movements to create a counter-hegemony in the field of civil society. Gramsci thus placed emphasis on civil society as a battlefield for hegemony, where the socialists must achieve popular agreement. Moreover, through the idea of this struggle for hegemony, he also actualized a Marxian viewpoint: "re-subsumption of the state to civil society" (Hirata 1993, 255-56).

Along with Hirata's devotion to Gramsci, the implications of his civil society began to transform from a notion concerning ordinary economic lives to one concerning political movements, from an expression of independent individuals 
to that of social individuals in solidarity, and from something to be realized and developed in Japan to a battlefield in advanced countries for hegemony. We also witness a deflation of his former question vis-à-vis the differences between Western Europe and Japan with regard to civil society. This may be a necessary change that originated from the new problematic approach to "civil society and the state." In any case, Hirata-by way of Gramsci's civil society theory-returned to the discipline of political economy: régulation theory. He approached, in a very peculiar manner, this new political economy that has risen in France since the 1970 s.

2. As is well known, régulation theory, by exploring new concepts such as "regime of accumulation" and "mode of régulation," was the first to analyze the dynamics of advanced forms of capitalism in the postwar age as being manifestations of the "growth and crisis of Fordism." This approach has now become a political economy that presents real-time analyses of contemporary economies (e.g., the collapse of socialist economies, varieties of capitalism, developing economies, and the growth and breakdown of finance-led capitalism). Hirata's interest in this theory lies not in its aspect of analyzing actual economic societies, but in its position in the history of economic thought, especially in the genealogy of the concept of régulation. He is persistently a historian of economic thought, even when handling contemporary political economy.

His characteristic understanding of régulation theory is typically expressed in the following opinions: "the concept of hegemony has prepared that of régulation" (Hirata 1993, 269), and "the regulationists found their basic concept in Gramsci” (Hirata 1988, 21). Of course, it is admitted by the French regulationists themselves (Lipietz 1985, 16) that the regulationist concept of "Fordism" has its origin in Gramsci (1971). However, Hirata intended to find the origin of the concept of "régulation" in Gramsci's concept of "hegemony." Hirata argues as follows.

According to Gramsci, civil society is a field where various classes and interest groups struggle with one another in search of their own hegemony, make compromises, and eventually arrive at social agreements. It is a field where domination is conducted through agreements, and where the old regime of domination may be overthrown. The virtue of the régulation school, says Hirata, is found in the fact that it has emphasized the standpoint that various compromises in civil society would be embodied in a series of "institutions."

Here, one can take the perspective of "institutional forms," or that of various institutions in the domains of the wage-labor nexus, forms of competition, forms of money and finance, the state, etc. The state is also considered "an institutionalized compromise." In a particular time and country, the ensemble of in- 
stitutional forms constitutes particular norms, rules, and habitus-all of which, as a particular "mode of régulation," will support an economic structure of the capitalism of the time. It is in this thinking that reside the novelty and relevance of régulation theory, which goes beyond the traditional economics that have narrowly limited the optics in analyzing markets. In Hirata's words, "As far as the hegemony is established exactly in the agreement in the civil society, the apparatus of hegemony can get a reality of the political economy only when it is comprehended in the institutional forms and modes of régulation as a social formation of agreement" (Hirata 1988, 20). He calls attention to references to Gramsci by Michel Aglietta, the founder of régulation theory:

The unification of these descriptive investigations with more fundamental valuable analysis of the determinants of social institutionalization should probably take its concepts from the work of Gramsci. By developing the Gramscian concept of the hegemony of a social class in the specific conditions of each nation, it may be possible to overcome the various traps of a structuralism of instances, a sovereign state manipulating macro-economic variables, or an instrumental state in the hands of the monopolies.

(Aglietta 1979, 29)

Thus, Hirata in his later years, in tracing the genealogy of the concept of régulation, eventually found it in the Gramscian understanding of civil society or hegemony. This is an approach to the authentic genealogy of-or, from the viewpoint of the history of economic thought, related to-régulation theory. One might say that here Hirata is a historian of economic thought through and through.

\section{What Was Hirata's Thinking on Civil Society?}

Having acquired his own perspective on the "circuit of productive capital and the structure of reproduction" from his study of Quesnay's Tableau économique, Hirata explored, through examinations of Marx's circuit theory since the mid1960s, a new approach to property theory. The latter led him, via the perception of the reversion of the law of appropriation, to the problematic field of "civil society and capitalism" - and also, via the attention to Marx's words about the re-establishment of individual property, to that of "civil society and socialism." When Japan's postwar capitalism was being established with an eye to achieving a high rate of economic growth, and when the many negative aspects of socialist countries were becoming clear, his civil society-centered Marxology caused a great sensation. During the collapse of socialist countries around 1990, 
Hirata adopted the thinking of Gramsci, thus shifting to the "civil society and the state" framework that places emphasis on the struggle for hegemony in the battlefield of civil society.

We can see in Hirata's personal history the predominance of his basic viewpoint: a critical understanding of economic society in terms of "circuit and reproduction" or "process and structure." Of course, his viewpoint sometimes experienced subtle shifts or biases. Starting from the perspective of "process and structure" in his younger days, he developed his own thinking vis-à-vis civil society by making positive the standpoint of "process," or by drawing back that of "structure." This reflects on his approach to régulation theory: his discussion of it is more biased toward the concept of "mode of régulation" than toward that of the "regime of accumulation," or macroeconomic structure. His death may have hindered him from undertaking a full discussion on the "regime of accumulation"-another pivotal concept of régulation theory that might also correspond to his own concept of "structure."

Following Hirata's death, we have seen the rise of (and boom in) new theory pertaining to civil society, originally triggered by the Eastern European civil revolutions and by the work of Habermas (1990). Where is Hirata's place in such contemporary research? One study says that Hirata in his later days became "a pioneer of the worldwide "boom of civil society theory" (Yamaguchi 2004, 111). Alternatively, referencing the works of the Japanese Civil Society School, an American historian argues that only during the postwar era did civil society "generate the analytical and moral force necessary to make it meaningful as more than a translated term" (Barshay 2004, 194). According to yet another authority, although the theory of Hirata, as well as that of Uchida, constituted "phase one of the contemporary renaissance of civil society," it was "shortlived" and "its influence was weak" (Keane 1998, 13-14). Pointing to the confusion that surrounds Hirata's notions of civil society, a Japanese scholar states that with Hirata, "the 'Civil Society School of Marxism' has come to an end" (Uemura 2010, 260).

Ultimately, what is the essence of Hirata's theory? It seems appropriate to conclude that some aspects are outdated and others are, nonetheless, new. Today, after having witnessed the collapse of the socialist countries and experienced the resulting disappointment, his problematic approach to "civil society and socialism" may now attract less interest among people. In addition, the fact that civil society in Japan has progressed a little (though only a little) in tandem with the maturity of Japanese capitalism in the 21 st century may have "naturalized” everybody's consciousness vis-à-vis civil society, leading to fewer and fewer questions being asked about "civil society and the commune."

However, there are some aspects of his thinking that are still quite novel, 
even today. For example, from his problematic questions pertaining to "civil society and capitalism" and "civil society and the state," we might possibly draw some suggestions about the relationships among "market-state-civil society"; the balanced proportion among these three constitutes the main theme in the new theory of civil society. Besides-and this most definitely needs to be mentioned-his discussion on the "re-establishment of individual property," the very essence of his civil society thought, will need to be developed in any case, regardless of differences in politico-economic regimes: capitalism or socialism, liberalism or social democracy, or a finance-led regime or a welfare-led regime, among other regimes.

(Toshio Yamada: Professor Emeritus, Nagoya University)

\section{References (*: written in Japanese)}

Aglietta, M. 1979. A Theory of Capitalist Regulation: The US Experience. London: NLB.

Asai, K. and F. Wakamori, eds. 1983*. The Annotated Catalogue of Works of Kiyoaki Hirata. Tokyo: Not for Sale.

Barshay, A. 2004. The Social Sciences in Modern Japan: The Marxian and Modernist Traditions. Berkeley, Los Angeles and London: University of California Press.

Gramsci, A. 1971. Americanism and Fordism. In Selections from the Prison Notebooks of Antonio Gramsci, ed. and trans. by Q. Hoare and G. Nowell-Smith. New York: International Publishers, 279-318. This article was first written in Italian in 1934.

Habermas, J. 1990. Strukturwandel der Öffentlichkeit: Untersuchungen zu einer Kategorie der bürgerlichen Gesellschaft: mit einem Vorwort zur Neuauflage. Frankfurt am Main: Suhrkamp.

Hirata, K. 1965*. Creation of Economic Science: Tableau économique and the French Revolution. Tokyo: Iwanami Shoten.

—. 1966*. Political Economy and Philosophy of History in Marx. Shiso 502:11-18, 503:111-24, 506:106-22, 509:121-36. Also in Hirata (1971).

- 1969*. Civil Society and Socialism. Tokyo: Iwanami Shoten.

—. 1971*. Political Economy and Philosophy of History. Tokyo: Iwanami Shoten.

—. 1977*. Contemporary Socialism and the Civil Society and Socialism. Gendai no Riron. 165:110-33.

—. 1978. Sur la notion de propriété individuelle chez Karl Marx. Keizai Kagaku (Economic Science). Nagoya University. 25 (4): 1-23.

—. 1982*. Discourse on the Method of the Critique of Political Economy. Tokyo: Iwanami Shoten.

1987. La société civile japonaise contemporaine. Actuel Marx 2:65-71.

—.1988*. Political Economy of Social Régulation. Shiso 771:17-41.

-. 1993*. Civil Society and the Régulation. Tokyo: Iwanami Shoten.

Keane, J. 1998. Civil Society: Old Images, New Visions. Cambridge: Polity Press.

Lipietz, A. 1985. Mirages et miracles: problèmes de l'industrialisation dans le tiers monde. Paris: La Découverte.

Marx, K. 1967. Le Capital. Tokyo: Far Eastern Book Sellers, Publishers. This is the first reprint of the first French edition published in Paris: Maurice Lachâtre et $C^{\text {ie }}, 1872-1875$. 
- 1973. Grundrisse: Introduction to the Critique of Political Economy. Harmondsworth: Penguin Books. This is an English translation of Grundrisse der Kritik der politischen Ökonomie (Rohentwurf) 1857-1858. Berlin: Dietz Verlag, 1953.

—. 1996. Capital, vol. 1. In Karl Marx-Friedrich Engels Collected Works, vol. 35. New York: International Publishers. This reproduces the first English edition published in 1887, translated from the third German edition by S. Moore and E. Aveling.

Mizuta, H. 2006. The Japanese Concept of Civil Society and Marx’s bürgerliche Gesellschaft. In Marx for the 21st Century, ed. by H. Uchida. London and New York: Routledge, 10920.

Nozawa, T. 2008*. Addition and Supplement to The Annotated Catalogue of Works of Kiyoaki Hirata. Chiba Daigaku Keizai Kenkyu (Economic Journal of Chiba University) 23 (2): 51-82.

Souzou-no-kai, ed. 1996*. Republic of Literature: In Memory of Hirata Kiyoaki. Tokyo: Not for Sale.

Suzuki, N. 2013. Uchida Yoshihiko: A Japanese Civil-Society Economist and Historian of Economic Thought of Postwar Japan. History of Economic Thought 55 (1): 1-17.

Uchida, Y. 1967*. Images of Japanese Capitalism through the Social Sciences. Tokyo: Iwanami Shoten.

Uemura, K. 2010*. What Is Civil Society?: Genealogy of Basic Concepts. Tokyo: Heibonsha.

Yamada, T. 1987. Les tendances du marxisme japonais contemporain. Actuel Marx 2:34-44.

—. 1988. Etat actuel de la théorie de la société civile. Osaka City University Economic Review 23:1-17.

—. 1998. Economic Development and Economic Thought after World War II: Economic Development and Marxian Political Economy. In Economic Thought and Modernization in Japan, ed. by S. Sugihara and T. Tanaka. Cheltenham and Northampton: Edward Elgar, 152-70.

Yamaguchi, Y. 2004*. Civil Society: Historical Inheritance and New Developments. Tokyo: Yuhikaku Publishing. 